\title{
Study of Water Quality Indicators of Mountain Rivers Used as Source of Drinking Water Supply of the Târgu - Jiu Municipality
}

\author{
DELIA NICA-BADEA ${ }^{1 *}$, SIMONA BRANDIBUR ${ }^{2}$ \\ ${ }^{1}$ Constantin Brâncuși University, Faculty of Medicinal and Behavioral Sciences, 30 Eroilor Str., Targu - Jiu, Romania \\ ${ }^{2}$ Gorj Water Management System - Water Quality Laboratory Târgu Jiu, 99 Ecaterina Teodoroiu Str., Targu-Jiu, \\ Romania
}

\begin{abstract}
Water quality criteria are all physicochemical and biological indicators that characterize a body of water. The current study aims at investigating the quality of two natural waters in the Gorj County sub-mountainous area (Şuşiţa, Vaidei and Runc, capture Runc) used as drinking water sources of Târgu-Jiu. Sampling and determinations use spectrophotometric, gravimetric, volumetric or electrometric techniques in accordance with standard methods (SR ISO and / or SR EN) for a series of physicochemical indicators analyzed between January - December 2017: thermal and acidification, oxygen regime, nutrients, salinity, relevant pollutants. Experimental values, annual averages related to the quality standards for potable water, ecological status and classification of water bodies, place the water of the two rivers in the drinking water category Al and the first class of ecological quality. The Water Quality Index (WQI) for 9 selected parameters highlighted a sensitively close overall level of the water of the two rivers Şuşita (88) and Runc (85.2), the good quality category (7o-9o), reported to national quality standards for surface water which can be used for delivery as drinking water.The study of indicators of the two rivers in relation to national rules aligned with the European water requirementsand research shows a high qualitative status corresponding to community uses.
\end{abstract}

Keyword: physicochemical parameter, water quality indicators, Șușiț, Runc, water quality index

Water quality requirements vary depending on the demand for drinking water for human consumption or industrial water. Depending on the nature of the raw water and the sector of use, the resources are selected and the degree of treatment of raw water.Fresh water represents a very low percentage of the Earth's total water content, ie $2.5 \%$ of surface water, but only $0.6 \%$ is directly accessible through springs, rivers, lakes, underground waters as vital resources for the current population [1].As a renewable, vulnerable and limited natural resource, water is considered a natural heritage that must be protected and preserved. The importance of water quality conservation has led to the monitoring and assessment of watercourses at regional, national and European level [2].

According to the requirements of Law 310/2004 and 311/2004 [3, 4], which took over the provisions of the Water Framework Directive 60/2000 / EEC [5] and other EU Directives, the national water monitoring system comprises two types of monitoring: surveillance and operational monitoring surveillance applied to bodies of water at risk of failing to meet water protection objectives. From the point of view of the environmental indicators, the surface water body in Romania in the year 2018 is in moderate $45 \%$ and high $55 \%$ [6].

Water quality assessment can be defined as assessing the physical, chemical and biological nature of water in relation to natural quality, human effects and intentional uses. Parameters analyzes that determine the quality of surface water bodies follow the main quality indicators according to quality standards, thermal regime and acidification, oxygen regime, nutrients, salinity, specific toxic pollutants of natural origin, other relevant physicochemical and biological indicators. Most water quality assessment studies generally use reports of the maximum admissible concentrations in relation to national, international or statistical and mathematical models, among which are the Water Quality Index (WQI), the Water Pollution Index ( WPI) and river habitats survey (RHS) [7-13].

Rivers are the main source of drinking and industrial water in Romania. The main rivers that have the upper basins in the high mountain area of Gorj have high annual average flows, provide natural water supplies or are sources of water supplies for towns and rural communities. The water quality in the Gorj Rivers is periodically monitored by Jiu Water Basin Administration, Gorj Water Management System, analyzing the main quality indicators according to the chemical and physico-chemical quality standards in river water. Based on the surface water characteristics used to produce potable water, three categories of standard river water treatment technologies are defined for drinking, to which the experimental results obtained are reported: A1, A2 and A3 [14].

*email: nicabadeadelia@yahoo.com 
The present study focuses on the analysis of the main water quality indicators of two mountain rivers in the subCarpathian of Gorj County (Şuşiţa, Stăneşti Commune and Runc, Runcu Commune), water supply sources for the water purification and treatment stations for $\mathrm{Tg}$ Jiu and other settlements on the river bed. River water quality parameters are reported to national and European standards for surface water quality, based on maximum allowable concentrations and water quality index (WOI).

\section{Experimental part}

Water samples were taken from the rivers of Şuşiţa (capture of Vaidei) and Runc (capture of Runc) during 2017 (January-December), rivers included in the Jiu Water Basin Administration, Gorj Water Management System. The sampling was performed by the Water Quality Laboratory, in accordance with the standards in force SR ISO 5667-6: 1997 [15], using plastic containers, washed with water at the sampling points, filled with water and sealed. Analyzes of physicochemical indicators were performed according to Romanian standard methods, approved internationally (SR ISO and / or SR EN), using reference materials, high purity chemical reagents using spectrophotometric, gravimetric, volumetric or instrumental techniques (Table 1).

Table 1

STANDARDS FOR QUANTIFICATION OF DETERMINED PHYSICO-CHEMICAL PARAMETERS

\begin{tabular}{|c|c|c|c|}
\hline Indicators & Standard methods & (DL) & (QL) \\
\hline Suspended matter $(\mathrm{mg} / \mathrm{L})$ & SR EN $872 / 2005$ & 1.4 & 5 \\
\hline Temperature water/air $\left({ }^{\circ} \mathrm{C}\right)$ & SR EN $1622 / 2007$ & - & - \\
\hline Dissolved Oxygen DO(mg/L) & SR EN 25813/2000 & 0.4 & 1.2 \\
\hline Oxygen saturation (\%) & SR EN25813/2000 & - & - \\
\hline Chemical oxygen demand COD $\mathrm{Cr}(\mathrm{mg} / \mathrm{L})$ & DIN 38409-H44/2008 & 1.5 & 5 \\
\hline Biochemical Oxygen DemandCBO ${ }_{5}(\mathrm{mg} / \mathrm{L})$ & SR EN 1899-2/2002 & 0.15 & 0.5 \\
\hline Conductivity & SR EN 27888/1997 & 1.6 & 2.5 \\
\hline Filterable residue at $105^{\circ} \mathrm{C}(\mathrm{mg} / \mathrm{L})$ & STAS 9187/1984 & 3 & 10 \\
\hline $\mathrm{pH}$ at $20.3^{\circ} \mathrm{C}(\mathrm{u} \mathrm{pH})$ & SR ISO 10523/2012 & - & 2 \\
\hline alkalinity (mg/L) & SR ISO $9963-1 / 2002$ & 0.17 & 0.4 \\
\hline $\mathrm{N}^{-\mathrm{NH}_{4}}{ }^{-}(\mathrm{mg} / \mathrm{L})$ & SR ISO $7150-1 / 2001$ & 0.018 & 0.025 \\
\hline $\mathrm{N}-\mathrm{NO}_{2}{ }^{-}(\mathrm{mg} / \mathrm{L})$ & SR EN 26777/C91/2006 & 0.002 & 0.003 \\
\hline $\mathrm{N}_{-N \mathrm{~N}_{3}}{ }^{-}(\mathrm{mg} / \mathrm{L})$ & SR ISO $7890-3 / 2000$ & 0.004 & 0.01 \\
\hline Ntot $(\mathrm{mg} / \mathrm{L})$ & SR EN ISO $11905-1 / 2003$ & 0.1 & 0.5 \\
\hline $\mathrm{P}-\mathrm{PO}_{4}^{3-}(\mathrm{mg} / \mathrm{L})$ & SR EN $6878 / 2005$ & 0.006 & 0.012 \\
\hline Ptot $(\mathrm{mg} / \mathrm{L})$ & SR EN $6878 / 2005$ & 0.004 & 0.007 \\
\hline Chlorides (mg/L) & SR ISO 9297/2001 & 2.200 & 5 \\
\hline Sulfates $(\mathrm{mg} / \mathrm{L})$ & EPA 375.4:2005 & 2.02 & 5 \\
\hline Fe total $(\mathrm{mg} / \mathrm{L})$ & SR ISO $6332 / 1996$ & 0.040 & 0.090 \\
\hline Mangan total (mg/L) & SR ISO 6333/1997 & 0.023 & 0.054 \\
\hline Bicarbonate (mg/L) & Calcul & 10.37 & 24.4 \\
\hline Detergents (mg/L) & SR EN $903 / 2003$ & 0.05 & 0.1 \\
\hline Phenols (mg/L) & SR ISO 6439/2001 & 0.001 & 0.003 \\
\hline Fluoride $(\mathrm{mg} / \mathrm{L})$ & Metoda 8029 - Hach DR2800 & 0.02 & 0.10 \\
\hline Cyanide $(\mathrm{mg} / \mathrm{L})$ & Metoda 8027 -Hach DR 2800 & 0.002 & 0.010 \\
\hline Extractable substances(mg/L) & SR7587/1996 & 5.3 & 20 \\
\hline Petroleum products (mg/L) & SR $7877-1 / 1996$ & 5 & 10 \\
\hline
\end{tabular}

(DL)Detection Limit; (QL) Quantification Limit

Determination of concentrations of $\mathrm{NH}_{4}{ }^{+}, \mathrm{N}-\mathrm{NO}_{3}{ }^{-}, \mathrm{P}_{-} \mathrm{PO}_{4}{ }^{3-} ; \mathrm{SO}_{4}{ }^{2-}$, detergents, phenols, metals were made using CAMSPEC M330 B Spectrophotometer, measuring range $\lambda-190-900 \mathrm{~nm}, \mathrm{pH}$ meter WTW InoLab 720 for sample $\mathrm{pH}$. Volumetric concentrations of chlorine, dissolved oxygen and biochemical oxygen demand (BOD5) were determined using Hirschmann Laborgerate biurette, AS class, div. $0.05 \mathrm{~mL}$, and chemical oxygen demand (CODCr) level with Biuretto $10 \mathrm{ml}$ Energo Metro. Verification of standardization of methods was done by plotting calibration curves, instrument recalibration and statistical processing for all analytical determinations. For confirmation, we present the calibration curves for the determination of the nitrate content, the spectroscopic method with sulfosalicylic acid, the SR ISO 7890-3 / 2000 method standard, CAMSPEC: $\lambda$ - 415nm, 40 mm cuvettes, range 0.15 - $5 \mu \mathrm{g} \mathrm{N}^{-\mathrm{NO}_{3}}{ }^{-}$(Fig. 1). 

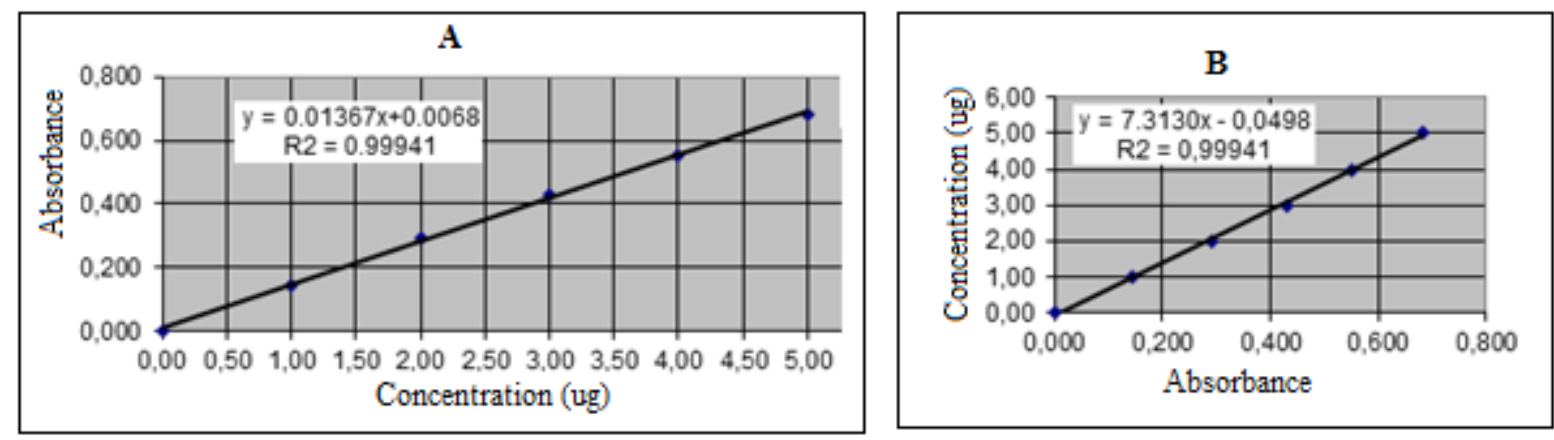

Fig. 1. Calibration curve for nitrates: A - Calibration function; B - Analytical function

In the assessment of water quality are presented a series of models - water quality index (WOI) models, depending on the nature of the parameters considered [16-18]. For this study, the water quality index formula / model applied by Mr. Brian Oram, PG, (2010) (formula 1) was applied:

$$
W Q I=1 / 100\left(\sum_{i=1}^{9} q_{i} w_{i}\right)^{2}
$$

where $\mathrm{i}$ - the quality parameter; qi - the registered value; wi - the rank of implication of the parameter in the computation formula. The steps of applying this methodology are: selection of the parameters, bringing the measurement units to the same scale, the determination of the weight of each parameter, the calculation of the water quality index and the establishment of the use domain.The water quality index (WQIi) varies between 0-100 and qualitatively assesses the importance and type of water quality by achieving a five-level classification: 90-100excellent; 70-90 Good, 50-70 Medium, 25-50 Bad, 0-25 Very bad. Recently an online computer water quality index program has been completed based on the Field Manual for Water Quality Monitoring, Brian Oram (2010).

\section{Results and discussions}

Physicochemical parameters

The results of quantification of the water physicochemical parameters of the rivers selected for potable water consumption and the consumption of the population from Targu-Jiu Municipality are presented in Table 2.

Table 2

ANNUAL AVERAGE VALUES OF SOME QUALITY INDICATORS OF RIVERS ȘUSTIȚA AND RUNC

\begin{tabular}{|c|c|c|c|c|c|c|c|c|}
\hline & \multicolumn{3}{|c|}{ Sușita River } & \multicolumn{3}{|c|}{ Runc River } & \multicolumn{2}{|c|}{ M.a.c. } \\
\hline $\begin{array}{c}\text { Indicators } \\
1\end{array}$ & $\operatorname{Min}_{2}$ & $\underset{3}{\operatorname{Max}}$ & $\begin{array}{c}\text { Med. } \\
4\end{array}$ & $\underset{5}{\operatorname{Min} .}$ & $\begin{array}{c}\operatorname{Max} . \\
6 .\end{array}$ & $\begin{array}{c}\text { Med. } \\
7\end{array}$ & $\begin{array}{c}\text { A1.[14] } \\
8\end{array}$ & $\begin{array}{c}\text { I. [19] } \\
9\end{array}$ \\
\hline T water/air ( $\left.{ }^{\circ} \mathrm{C}\right)$ & $3 / 11$ & $17 / 29$ & $11 / 16.5$ & $6 / 11$ & $19 / 30$ & $11.7 / 19.5$ & - & - \\
\hline Turbidity (mg/L) & 11 & 19,0 & 14.75 & 14,0 & 20.0 & 17.0 & 25 & - \\
\hline $\mathrm{DO}(\mathrm{mg} / \mathrm{L})$ & 9.5 & 13.0 & 11.55 & 8.9 & 11.8 & 10.45 & - & 9 \\
\hline Saturation (\%) & 99.3 & 101.0 & 99.80 & 97.8 & 98,7 & 98.20 & $>70$ & $>90$ \\
\hline CBO5 $(\mathrm{mg} / \mathrm{L})$ & 0.70 & 1.00 & 0.76 & 1.10 & 1.12 & 1.15 & $<3$ & 3 \\
\hline $\mathrm{COD} / \mathrm{r}(\mathrm{mg} / \mathrm{L})$ & $<5.00$ & 7.00 & 5.60 & 5.4 & 7 & 6.20 & - & 10 \\
\hline Conduc. $(\mu \mathrm{S} / \mathrm{cm})$ & 92.50 & 124.2 & 107.62 & 184.1 & 200.0 & 190.4 & 1.000 & - \\
\hline Residues (mg/L) & 60.20 & 81.40 & 68.82 & 72.3 & 142.3 & 110.50 & - & 500 \\
\hline $\mathrm{pH}(\mathrm{u} \mathrm{pH})$ & 7.37 & 7.71 & 7.57 & 7.57 & 7.96 & 7.80 & $6.5-8.5$ & $6.5-8.5$ \\
\hline $\mathrm{N}^{-\mathrm{NH}_{4}{ }^{+}(\mathrm{mg} / \mathrm{L})}$ & & & $=0.025$ & & & $<0.025$ & 0.05 & 0.4 \\
\hline $\mathrm{N}^{-\mathrm{NO}_{2}}{ }^{-}(\mathrm{mg} / \mathrm{L})$ & & & $=0.003$ & & & $<0.003$ & - & 0.01 \\
\hline $\mathrm{N}^{-\mathrm{NO}_{3}}{ }^{-}(\mathrm{mg} / \mathrm{L})$ & 0.26 & 0.38 & 0.36 & 040 & 0.31 & 0.35 & 25 & 1.0 \\
\hline Ntot (mg/L) & & & $=0.50$ & $<0.50$ & 0.51 & 0.50 & 1.0 & 1.5 \\
\hline $\mathrm{P}-\mathrm{PO}_{4}{ }^{3-}(\mathrm{mg} / \mathrm{L})$ & $<0.012$ & 0.028 & 0.019 & $<0.012$ & 0.025 & 0.019 & 0.4 & 0.1 \\
\hline Ptot. $(\mathrm{mg} / \mathrm{L})$ & 0.009 & 0.031 & 0.020 & 0.011 & 0.033 & 0.024 & - & 0.15 \\
\hline $\mathrm{Cl}^{-}(\mathrm{mg} / \mathrm{L})$ & & & $<5$ & & & $<5$ & 200 & 25 \\
\hline $\mathrm{SO}_{4}{ }^{2-}(\mathrm{mg} / \mathrm{L})$ & 9.08 & 14.70 & 10.51 & 8.47 & 12.88 & 11.35 & 150 & 60 \\
\hline Detergent $(\mathrm{mg} / \mathrm{L})$ & & & $=0,1$ & & & $<0.1$ & 0.2 & 100 \\
\hline Phenols (mg/L) & & & $=0.003$ & & & $<0.003$ & 0.001 & $1.0 \mathrm{FI}$ \\
\hline Fe tot. (mg/L) & & & $<0.09$ & & & $<0.09$ & 0.1 & 0.3 \\
\hline $\mathrm{Mn}$ tot. $(\mathrm{mg} / \mathrm{L})$ & & & $<0.05$ & & & $<0.05$ & 0.05 & 0.05 \\
\hline
\end{tabular}

aSource: Gorj Water Management System, Water Quality Laboratory, 2017.

M.a.c.-Maximum admissible concentrations:

A1- Category 1 of surface water for potable water [14];

I - Ecological quality class I, Ecological status [19];

FI - phenolic index 
The analysis of the results of the determinations presented in Table 2 are related to the quality standards that the waters of surface area used for potable water and the Norms on measuring methods and frequency of sampling and analysis of samples from surface water intended for the production of drinking water [14].The results of quantification of the water physicochemical parameters of the rivers selected for potable water and the consumption of the population from Targu-Jiu (Table 2).

The analysis of the results of the determinations presented in Table 2 are related to the quality standards that the waters of surface area used for potable water and the Norms on measuring methods and frequency of sampling and analysis of samples from surface water intended for the production of drinking water according to GD 567/2006 [14].According to the quantitative physical and chemical parameters (Annex 1b, NTP13), three categories are established for categorizing the rivers in the drinking criteria: category A1 - simple physical treatment and disinfection; category A2 - normal physical, chemical and disinfection treatment; category A3 - advanced physical treatment, perchloration and disinfection.

By comparing the values of the physical-chemical quality indicators determined by the quality norms that must be met by the surface water used for potable wateraccording to GD no 567 of 2006), it is found that all the quality criteria of the parameters determined for the two rivers in the sub-Carpathian area, they are in the A1 category of water sources. The mean values of the analyzed indicators are sensitively close to the two rivers, where most of the concentrations are well below the limits set by quality standards (Table 2, column 8) or above the value of the quality standard at the dissolved oxygen saturation indicator with mean values $99.80 \%$ Sușița and $98.20 \%$ Runc, even with monthly $100 \%$ saturation values. The physicochemical level of parameters highlights the quality of water in these rivers that qualifies it for minimal operations for drinking: simple physical treatment and disinfection and low pollution of the adjacent area.

\section{Ecological status.}

Reporting the determined parameters (Table 2) to the biological, chemical and physico-chemical quality indicators for establishing the ecological status according to OrderMMGA161 16/02/2006 (table 6 C), assessing the ecological status of the two rivers in order Şuşiţa and Runc [19].The thermal regime, natural water temperature of 11 to $16.5^{\circ} \mathrm{C}$ and 11.7 to $19.5{ }^{\circ} \mathrm{C}$, vary depending on the origin and the season, and can be considered an indirect indicator of pollution and acidification. The $\mathrm{pH}$ of the analyzed water that defines the neutral, alkaline or acid character of the water with annual average values ranging from 7.57 and 7.80, includes them in ecological quality class I. The average dissolved oxygen concentrations (DO) of 11.55 and $10.45 \mathrm{mg} / \mathrm{L}$ relative to the standard of $9 \mathrm{mg} / \mathrm{L}$ for class I place the two rivers taken into study in class I of ecological quality and in the Epilimnion category (stratified waters 90 $110 \%$ ) with average values of $99.80 \%$ and $98.20 \%$ respectively. Biochemical oxygen demand-BOD5, which provides valuable information on the level of water pollution with organic substances showing average values of $0.76 \mathrm{mg} / \mathrm{L}$ and $1.15 \mathrm{mg} / \mathrm{L}$, compared to $3 \mathrm{mg} / \mathrm{L}$ for the first class, and CODCr with average values of $5.6 \mathrm{mg} / \mathrm{L}$ and $6.20 \mathrm{mg} /$ $\mathrm{L}$, compared to the norm of $10 \mathrm{mg} / \mathrm{L}$ for Class I, places the two rivers in first class of ecological quality. Annual

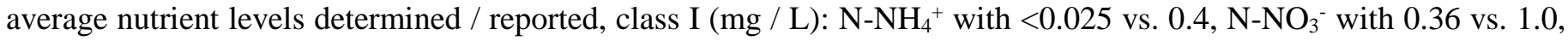
$\mathrm{N}-\mathrm{NO}_{2}{ }^{-}$with $<0.003$ vs. $0.01, \mathrm{P}^{-\mathrm{PO}_{4}{ }^{3-}<0.019}$ vs. 0.1 , reflects a high degree of ecological status of these mountain rivers well below the normative values of class I indicators. The same classification (classI) also applies to total nitrogen, total phosphorus, specific conductivity, chloride, sulfate or specific toxic pollutants of natural origin: $\mathrm{Fe}, \mathrm{Mn}$ and other relevant chemical analytes, such as detergents or phenols, (col. 8 Table 2).

\section{Water Quality Index}

To assess the level of pollution and at the same time to express the water quality, the quality index (WQI) of some rivers at the national level was used [20-23, 1, 13]. The determination of the WQI index for the two rivers comprises nine physico-chemical and biological indicators: turbidity, $\mathrm{DO}$ saturation, $\mathrm{pH}, \mathrm{BOD}$, temperature change, $\mathrm{P}_{-} \mathrm{PO}_{4}{ }^{3-}, \mathrm{N}-$ $\mathrm{NO}_{3}{ }^{-}$, total solids computed using on-line computerized software [Brian Oram, PG, 2010]. The results of the application of the calculation program to the selected parameters are presented in table 3 and fig. 2.Individual WQI differences with lower values in relation to the standards, are found in particular in the following indicators (ȘusițaRunc): temperature change 73 versus 56; turbidity 86 versus 82 ; total solid particles 88 versus 85 . Individual differences may have an explanation for the relatively arid run of the Runc River, located in the vicinity of a currently degraded limestone quarry, compared to the river Şuşiţa (popularly called Şuşiţa -Green) with a lot of forest vegetation that ensures a lower temperature regime and a turbidity or slightly different solids. It is noteworthy that some individual quality parameters are at very high levels of standardized WQI quality indices, reaching values close to the maximum limit for both rivers: DO and 99 phosphates, nitrates 97, BOD 96 respectively 94.Globally, with WQI values of 88 versus 85.25, the two rivers fall into the Good Water Quality category (70-90) and thus with minimal technological potable operations - category A1, ensures good water supply of the population of Targu Jiu City. 
Tabel 3

WATER QUALITY INDEX DATA FOR RIVERS SELECTED

\begin{tabular}{|c|c|c|c|c|c|}
\hline Indicators & Weight & $\begin{array}{c}\text { Indicators } \\
\text { Sussita } \\
\text { (Med.) }\end{array}$ & $\begin{array}{l}\text { WQI } \\
\text { Șușița }\end{array}$ & $\begin{array}{l}\text { Indicators } \\
\text { Runc } \\
\text { (Med.) }\end{array}$ & $\begin{array}{l}\text { WQI } \\
\text { Runc }\end{array}$ \\
\hline OSaturation & 0.17 & 99.80 & 99 & 98.20 & 99 \\
\hline $\mathrm{pH}$ & 0.11 & 7.57 & 92 & 7.80 & 90 \\
\hline $\mathrm{BOD}_{5}$ & 0.11 & 0.76 & 96 & 1.15 & 94 \\
\hline T Change \pm & 0.10 & \pm 5 & 73 & \pm 8 & 56 \\
\hline Total P-PO4${ }_{4}^{3-}$ & 0.10 & 0.019 & 99 & 0.019 & 99 \\
\hline $\mathrm{N}^{-\mathrm{NO}_{3}}$ & 0.10 & 0.36 & 97 & 0.35 & 97 \\
\hline Turbidity & 0.08 & 14 & 69 & 17 & 65 \\
\hline Total Solids & 0.07 & 68.82 & 86 & 110,50 & 82 \\
\hline Overall WQI & - & - & 88 & - & 85.25 \\
\hline Range Quality ${ }^{2}$ & - & - & $\begin{array}{l}\text { Good } \\
70-90\end{array}$ & - & $\begin{array}{l}\text { Good } \\
70-90\end{array}$ \\
\hline
\end{tabular}

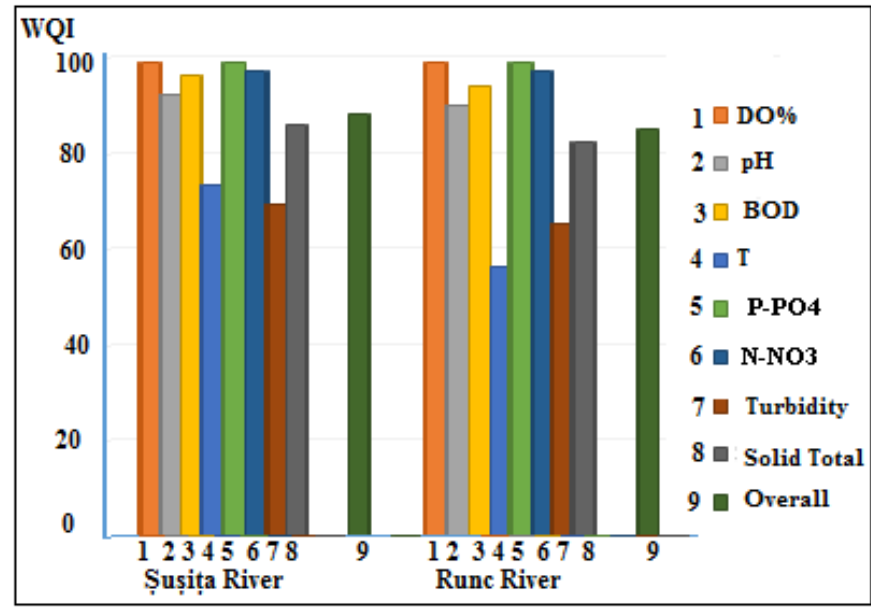

Fig. 2. Water Quality Index for rivers selected

The WQI level for the two mountain rivers ranging from 88-85.25 is within the variation limit of some rivers in Romania such as Timis River (2004-2014), at six sampling points with values of 81-86 [13]; Motru River 2000 - 2009 with values between 80-88 [21], and over the variation level of other rivers in the country such as: Bahlui rivers with WQI between: 53.893 - 64.345 [1]; Miletin River with WQI varies between 64-78, Halceni Dam range 65-82, Vlădeni Pond 61-81, Larga Jijia 59-81 and Jijia River 41-61, [20].

\section{Conclusions}

The physico-chemical parameters of water in selected rivers selected monthly in 2017 in the ABA-SDG Gorj laboratory, were compared (average values) by correlation with the national quality standards that surface waters used for drinking water have to meet, and establishing ecological status.

The comparative analysis of the determined physicochemical parameters revealed the classification of both rivers in A1 drinking category with the application of simple physical treatment and disinfection technology and the classification in ecological quality class I for all analyzed parameters (Order 161). Calculation of the WQI water quality index - the model agreed at European level and applied in this study to determine the ecological status determined the classification of these rivers globally with 88 Ș Șița and 85.25 Runc in the Good category (70-90).

The quality parameters determined, reported to the national standard, aligned with the European water requirements and the WQI water quality index compared to a series of national researches mentioned in the paper, highlight the special quality of river water, the low impact of factors anthropic environment, and polluting the flow area upstream of the capture stations of the two studied rivers, the only industrial activities being wood exploitation, limestone quarry and tourism.

\section{References}

1.ZAHARIA, C., J. Eng. Stud. Res., 21 (4), 2015, p.79.

2.GRIFFITHS, M., The European Water Framework Directive: An Approach to Integrated River Basin Management, European Water Management Online Official Publication of the European Water Association (EWA), 2002.

3.***Law 310 of 30 June 2004, amending and supplementing the Water Law no. 107/1996, Official Monitor of Romania, no. 584 of 30/06/2004.

4.***Law 311 of 28 June 2004, amending and supplementing Law no. 458/2002 on drinking water quality, Official Monitor of Romania, 1st part, no. 582 of 30/06/2004 
5.*** Water Framework Directive (2000/60/EC), Official Journal of the European Community, vol. L327, pp. 1-73, 2000.

6.***European waters - assessment of status and pressurest EEA Report No 7/2018. https://www.eea.europa.eu/publications/state-of-water

7.MILANOVIĆ, A., UROŠEV, M., MILIJAŠEVIĆ, D., Bull. Serbian Geograph. Soc., 86, no. 2, p. 53, 2006.

8.SANCHEZ, E.; COLMENAREJO, M.F.; VICENTE, J.; RUBIO, A.; GARCIA, M.G.; TRAVIESO, L.; BORJA, R., Ecol. Indic., 7, 2007, p.

315.

9.SERBAN, S.A., IONUS, O., Geographic Forum, Vol. X, No.1, ISSN: 1583-1523, Universitaria Publish, Craiova, 2011 , p. 195.

10.CRETESCU, I., CRACIUN, I., BENCHEA, R.E., KOVACS, Z., IAVORSCHI, A., SONTEA, S., MACOVEANU, M., Environ. Eng. Manag. J., 12, no. 8, 2013, p. 1721.

11.LOBATO, T.C., HAUSER-DAVIS, R.A., OLIVEIRA, T.F., SILVEIRA, A.M., SILVA, H.A.N., TAVARES, M.R.M., SARAIVA, A.C.F., J. Hydrol., 522, 2015, p. 674.

12.GUPTA, N., Pandey, P., Jakir Hussain, H., Water Sci., 31, no. 1, 2017, p.11.

13.DUNCA, A.M., Romania Journal of Chemistry, Volume 2018, Article ID 9073763, 8 pages https://doi.org/10.1155/2018/9073763.

14.*** DG no. 567, 26/04/2006, Official Monitor of Romania,1st part, no. 417 of 15/05/2006.

15.***SR ISO 5667-6:1997, Water Quality. Sampling. Guide for sampling of rivers and watercourses.

16.ORAM, B., WaterQuality Index Calculator, According to the book Field Manual for Water Quality Monitoring, 2010, Pennsylvania, USA,

2010. http://www .water-research.net/index.php/water-treatment/water-monitoring/

17.BHARTI, N, KATYAL, D., J. Environ. Sci., 2, no.1, 2011, p. 155.

18.TYAGI, S., SHARMA, B., SINGH, P., DOBHAL, R., J. Am. Water Resour. Assoc., 1, no. 3, 2013, p. 34.

19.***Order MMGA no. 161 of 16 February 2006, Official Monitor, no. 511 of 13/06/2006.

20.BREABĂN, I.G., GHEŢEU, D., PAIU, M., Bulletin UASVM Agriculture, 69(2), 2012, p.160.

21.IONUS, O., Annals University of Craiova, Series Geography, 13, 2010, p. 74.

22.ROMANESCU, G., HAPCIUC, O-E, SANDU, I., MINEA, I., DASCALITA, D., IOSUB, M., REV.CHIM.(Bucharest), 67, no.2, 2016, p.245.

23.PIŞTEA, I., UNGUR, A., ROBA, C., POPIŢA, G., ROŞU, C., Studia UBB Ambientum, LVIII, 1-2, 2013, p.. 87.

$\overline{\text { Manuscript received: } 21.12 .2017}$ 